\title{
STUDIES ON SYNGHRONISING SEED GERMINATION IN RED SANDERS (PTEROCARPUS SANTALINUS)
}

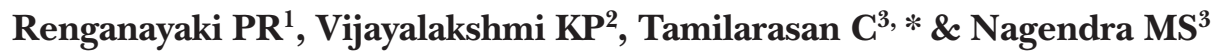 \\ ${ }^{1}$ Department of Seed Science and Technology, TNAU, Tamil Nadu, 641003 India \\ ${ }^{2}$ Department of silviculture, KAU, Kerala, 680656 India \\ ${ }^{3}$ Department of Seed Science and Technology, TNAU, Tamil Nadu, 641003 India \\ *tamilarasan2510@gmail.com
}

Submitted April 2019; accepted July 2019

\begin{abstract}
Pterocarpus santalinus is valued for its heavy, dark claret-red heartwood which possesses indomitable challenges in seed propagation. This study was conducted to improve seed germination in red sanders. Seeds and fruits were collected from the elite trees of Vellore district, Tamil Nadu to elicit information on the pod, seed germination and its improvement methods. Freshly collected and harvested seeds had poor germination $(33 \%)$ with germination period ranging between 14 to 53 days. The poor and staggered germinability of red sander was due to the presence of phenolic compounds and hormonal imbalance in pod and seed respectively. Significant increase in germination percentage with reduced germination period was observed when seeds were soaked for 48 hours and changing the water every 12 hours, followed by soaking in 500 ppm of $\mathrm{GA}_{3}$ for 12 hours. These combination of soaking the red sander seeds in water followed by $\mathrm{GA}_{3}$ can be employed for early synchronised higher germination.
\end{abstract}

Keywords: Seed dormancy breaking, manual clipping, phenol content, leaching, $\mathrm{GA}_{3}$ soaking, improved germination

\section{INTRODUCTION}

Pterocarpus santalinus belongs to the family Fabaceae, popularly known as red sanders. It is an endemic and endangered species confined to the Southern Indian peninsula. Red sander is a light loving tree grown in dry, hilly, rocky ground but occasionally found in windward side of the hills. Pterocarpsus is valued for its heavy, dark claretred heartwood, wavy grains and a red pigmented dye called santalin. Extremely hard, blood red heart wood with occasional light-yellow streaks, attracts the world market which is growing daily. Recently, the natural resource from the forests had almost come to an extinct. The species is regularly broadcasted in media for its unlawful felling. Government of India's has seized 15,000 crore rupees worth logs of red sanders. Besides overexploitation, poor natural regeneration, due to low and delayed time of germination $(20-35 \%$ in a period of 58 days), is a limiting factor for the expansion of this species (Naidu \& Rajendrudu 2001, Shilpa et al. 2012).

There are reports about seed dormancy, however the type of dormancy has yet been clarified (Padmalatha \& Prasad 2007, Rao \&
Raju 2002). Prolonged germination, up to $60^{\text {th }}$ day of sowing, is caused by low speed of germination (Kalimuthu and Lakshmanan 1995). Conventional vegetative propagation techniques, such as grafting and air-layering have limitations in large-scale multiplication of this species, and poor rooting from cuttings (Reddy \& Srivasuki 1990). Tissue culture has proved to be a promising technique for conservation and large-scale multiplication of several woody species. However, the Fabaceae family has difficulty with in vitro culturing. Air layers, when compared to stem cuttings, have robust and vigorous roots but the rate of manipulation is low and insufficient to transplant from nursery to main field (Rao \& Raju 2002). Based on the above reasons, the multiplication of the species largely depends on the seeds (Dayanand \& Lohidas 1988). Considering the commercial importance of Pterocarpus santalinus and problems faced in seed propagation, scientific knowledge on seed factors responsible for poor germination and methods to overcome the obstacles of germination is important but deficit. Hence, 
this study was carried with the aim to achieve synchronised germination through dormancy breaking techniques.

\section{MATERIALS AND METHODS}

Fresh seeds of $P$. santalinus collected during June 2017 from Vellore district, Tamil Nadu, India constituted the study material for the research program. Fifty seeds in eight replications were subjected to germination and viability test to obtain the initial seed quality, and 100 seed weight was recorded $(8 \mathrm{~g})$. On the other hand, seeds were analysed under x-ray radiography for seed filling percentage. The vast difference between viability test and germination percentage indicated the presence of dormancy. Assuming the presence of physical dormancy, seeds were subjected to the following treatments.

\section{Treatments to break seed dormancy}

\section{Clipping of pod}

Four hundred pods were damaged at the distal end using wire cutter or secateurs and pods were subjected for germination test (Figure 2).

\section{Lime combustion}

In lime combustion, $500 \mathrm{~g}$ of white lime was added to water and allowed for combustion. Four hundred pods were added and kept undisturbed for 24 hours.

\section{Lime combustion and jiggery}

Lime was allowed for combustion as per the above description, and during the process of combustion $200 \mathrm{~g}$ of jaggery and 400 red sanders pods were added and the mixture was kept undisturbed for 24 hours.

\section{Water soaking}

Four hundred pods with wings were soaked separately in water at different durations (24, 48 and 72 hours).

Alternate wetting and drying (AWD)

Soaking of 400 pods in water for 12 hours followed by 12 hours of drying constituted one cycle. Pods were subjected to one cycle (24 hours), two cycles (48 hours) and three cycles (72 hours) of AWD separately.

\section{Leaching of inhibitors}

After removal of shiny shell, 400 pods were soaked in water for three different durations (24, 48 and 72 hours); during soaking water was changed for every 12 hours duration and the water was collected. From the collected water, phenol content was estimated at three different soaking duration (24, 36 and 48 hours) (Figure 3) as per Malick \& Singh (1980).

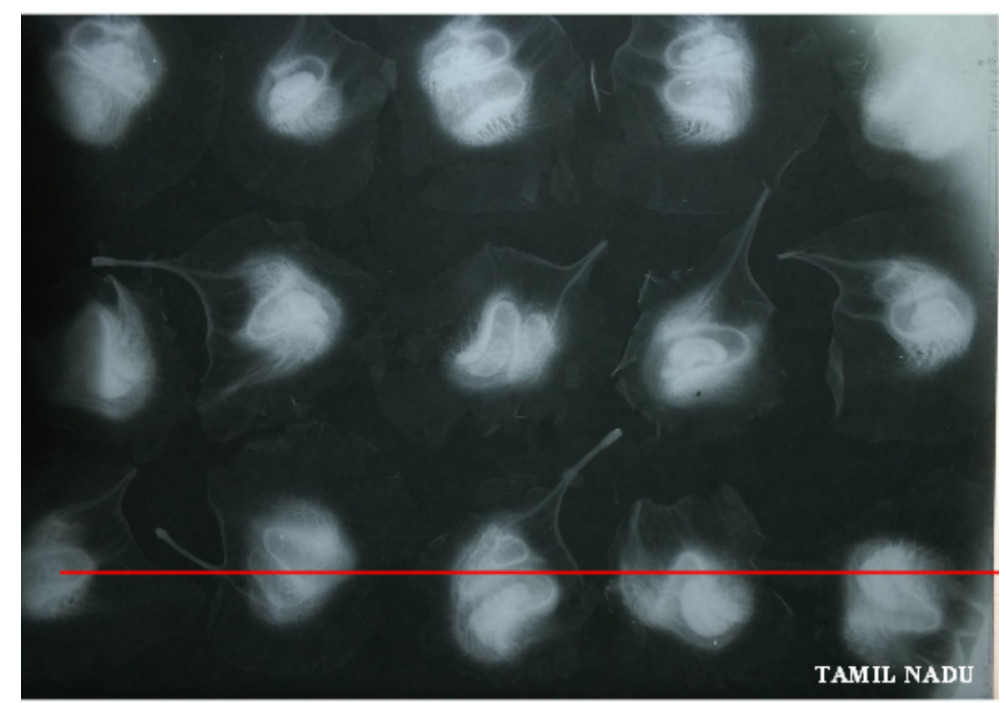

Figure 1 X-ray radiography analysis on seed filling (all the seeds in the image were filled) 

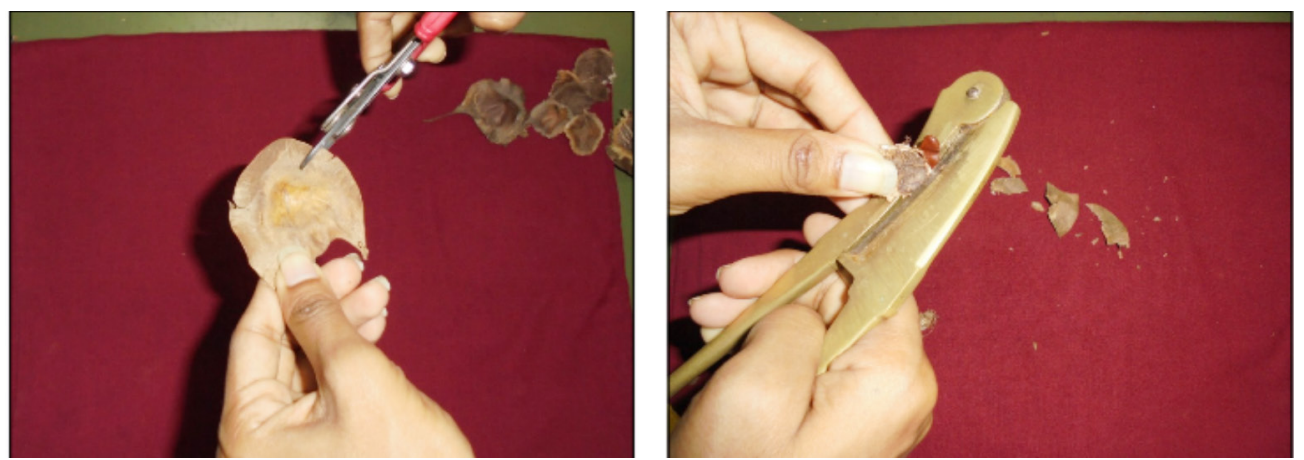

Figure 2 Removal of wing and clipping of pods of red sanders with the help of wire cutter

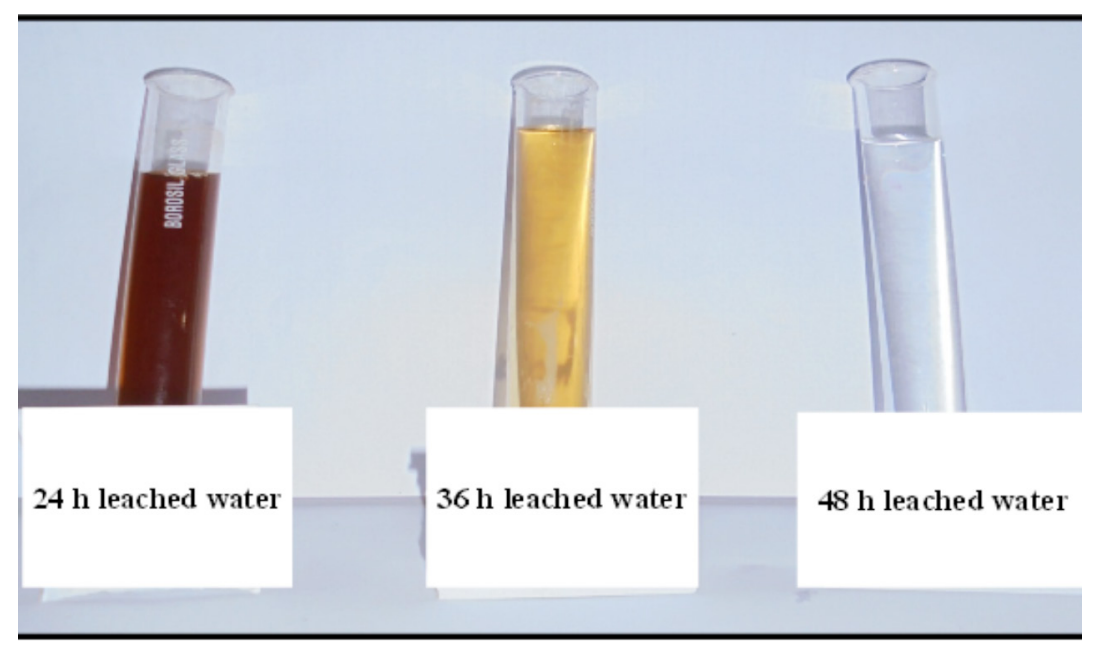

Figure 3 Colour of leached water indicating the phenol content of pods at different durations

Soaking in $\mathrm{GA}_{3}$

Pods leached for 72 hours were soaked in 500 ppm of $\mathrm{GA}_{3}$ for 12 hours. After the completion of the prescribed period of soaking, pods from every treatment were subjected to germination test. The observations recorded were germination percentage age and, days to initial and final germination.

\section{Speed of germination}

Eight replicates of 50 seeds each were germinated in sand medium. During germination test period, observations were made every day, from intial to final day of germination. The emergence of seedlings with cotyledons and plumule were counted daily. From the mean germination percentage recorded at each counting date, the rate of germination was calculated using the formula suggested by Maguire (1962):

Rate of germination $=\frac{\mathrm{X}_{1}}{\mathrm{Y}_{1}}+\frac{\mathrm{X}_{2}-\mathrm{X}_{1}}{\mathrm{Y}_{2}}+\ldots+\frac{\mathrm{X}_{\mathrm{n}}-\left(\mathrm{X}_{\mathrm{n}^{-1}}\right)}{\mathrm{Y}_{\mathrm{n}}}$ where, $\mathrm{Xn}=$ number of seedlings germinated on $\mathrm{n}^{\text {th }}$ count and $\mathrm{Yn}=$ number of days from sowing to $\mathrm{n}^{\text {th }}$ count.

\section{RESULTS AND DISCUSSION}

The pod enclosed sickle or kidney-shaped single seed, a typical characteristic of the red sander (Figure 1). The X-ray analysis indicated the presence of filled seed to $95 \%$. Seeds had well matured embryos and seed lots had $90 \%$ viable seeds (TZ test; Figure 4). However, when the seeds were allowed to germinate under laboratory conditions, it was noticed that only $33 \%$ of seeds germinated within the period of germination ranging from 14 to 53 days. This low germination, accompanied by a prolonged period of germination, indicated the presence of dormancy. With the assumption that dormancy may be due to hard seeds coat, physical dormancy breaking treatments were imposed. 


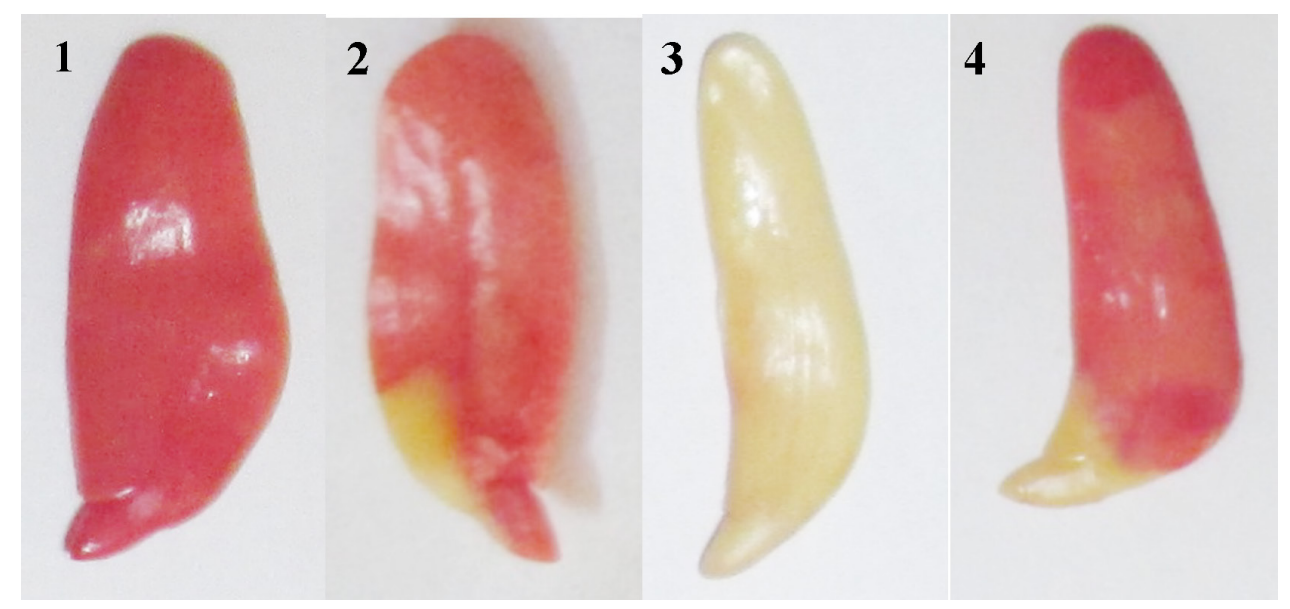

Figure 4 Staining pattern of viable and nonviable cotyledons; 1 and 2 = viable seeds, 3 and $4=$ non-viable seeds

The pods subjected to water soaking, 72 and 48 hours, recorded higher germination of 53 and $50 \%$ with a minimum germination period of 27 and 32 days respectively (Table 1). Increased germination and shortening of the period of germination could be due to softening of seed coat during water soaking, as reported by Thanuja et al. (2019). Out of the $90 \%$ viable seeds, only $53 \%$ of seeds germinated in water soaking, suggesting that hard seed coat is not the sole factor hindering germinability. Varying concentrations of seed coat phenols may result in varying degree and depth of dormancy which causes staggered release of dormancy or germination (Omakhua et al. 2015).

Furthermore, to increase the germination, physiological dormancy treatments, viz., different cycles of AWD, leaching and combination of leaching and $\mathrm{GA}_{3}$ were imposed (Table 2). Among the treatments, alternate wetting and drying for 48 hours recorded $73 \%$ germination with reduced germination period from 53 to 17 days. The effect of the treatment could be due to the expansion of cells during wetting and contraction during drying which resulted in weathering of the pod coat, which could have facilitated the imbibition process. Availability of sufficient water accelerated the breakdown of food material and synthesis of enzymes. A similar response was noticed (Maynard \& Gates 1963) in Agropyron desertorum.

To germinate the remaining seeds, leaching of phenols was carried out by changing the water at an interval of 12 hours which shortened the germination period rather than enhancing the germination percentage. The quickening of the germination process ( 53 to 16 days) by leaching confirmed that the mechanism behind low germination $(58 \%)$ is the presence of phenols. At the same time, leaching of phenol did not produce much effect on enhancing seed germination which confirmed that some other factor is controlling the dormancy, perhaps hormonal imbalance. Hence, leached pods (72 hours) were soaked in $\mathrm{GA}_{3}(500 \mathrm{ppm})$ for 12 hours which resulted in maximum germination $(88 \%)$ with reduced germination period from 53 to 14 days. Results obtained were in accordance with Archontophoenix alexandrae, Ptychospermam acarthuri and teak (Moussa et al. 1998, Baskin and Baskin 2004).

To confirm the results, phenols was estimated in the water collected during leaching. The colour of the water was dark brown even after 24 hours of leaching and phenol content recorded was $0.65 \%$, indicating that during leaching the seed coat phenolic compounds slowly dissolved in water. However, at 36 hours the phenol content was reduced to $0.42 \%$ with golden yellow colour solution and at 48 hours it was $0.02 \%$ with colourless solution (Figure 4 ).

\section{CONGLUSION}

Red sander is highly valued for its heavy, dark claret-red heartwood. Its mode of propagation is through seeds which possesses a major problem of dormancy for a period of one year, leading to poor and asynchronised germination. In order to resolve the issue and achieve uniform germination, the present study was formulated and executed to identify the various types of 
Table 1 Effect of physical treatments on seed germination improvement in red sanders

\begin{tabular}{lcccc}
\hline Treatment & $\begin{array}{c}\text { Days to initiate } \\
\text { germination }\end{array}$ & $\begin{array}{c}\text { Days to final } \\
\text { germination }\end{array}$ & $\begin{array}{c}\text { Speed of } \\
\text { germination }\end{array}$ & $\begin{array}{c}\text { Germination } \\
(\%)\end{array}$ \\
\hline $\mathrm{T}_{0}$-Control & 14 & 53 & 0.22 & 33 \\
$\mathrm{~T}_{1}$-Clipping of pod & 12 & 51 & 0.30 & 49 \\
$\mathrm{~T}_{2}$ - Lime combustion 24h & 11 & 27 & 1.27 & 43 \\
$\mathrm{~T}_{3}$ - $\mathrm{T}_{2}$ - jaggery combustion 24h & 11 & 27 & 1.40 & 47 \\
$\mathrm{~T}_{4}$-water soaking 24 hours & 9 & 34 & 0.45 & 45 \\
$\mathrm{~T}_{5}$-water soaking 48 hours & 7 & 32 & 0.47 & 50 \\
$\mathrm{~T}_{6}$-water soaking 72 hours & 8 & 27 & 0.53 & 53 \\
Mean & 11 & 36 & 0.66 & 46 \\
$\mathrm{SED}$ & 0.47 & 2.45 & 0.01 & 1.23 \\
$\mathrm{CD}(0.05)$ & $0.96 * *$ & $5.06^{* *}$ & $0.02 * *$ & $2.17 * *$ \\
\hline
\end{tabular}

** = Significantly differs

Table 2 Effect of alternate wetting and drying (AWD) and leaching of phenols (LP) on germination improvement in red sanders

\begin{tabular}{lcccc}
\hline Treatment & $\begin{array}{c}\text { Days to initiate } \\
\text { germination }\end{array}$ & $\begin{array}{c}\text { Days to final } \\
\text { germination }\end{array}$ & Speed of germination & Germination (\%) \\
\hline $\mathrm{T}_{0}$ - Control & 14.00 & 53.00 & 0.62 & 33 \\
$\mathrm{~T}_{1}$ - AWD 24 hours & 8.00 & 20.00 & 3.36 & 61 \\
$\mathrm{~T}_{2}$ - AWD 48 hours & 8.00 & 17.00 & 4.28 & 73 \\
$\mathrm{~T}_{3}$-AWD 72 hours & 7.50 & 17.00 & 3.56 & 61 \\
$\mathrm{~T}_{4}$-LP 24 hours & 7.50 & 19.20 & 2.84 & 54 \\
$\mathrm{~T}_{5}$ - LP 48 hours & 6.80 & 16.00 & 3.40 & 54 \\
$\mathrm{~T}_{6}$-LP 72 hours & 6.00 & 16.00 & 3.61 & 58 \\
$\mathrm{~T}_{7-} \mathrm{T}_{6}+\mathrm{GA}$ 500 ppm 12 & 7.00 & 14.00 & 7.20 & 88 \\
hours & & & & 60.25 \\
Mean & 8.10 & 21.53 & 3.61 & 1.02 \\
SED & 0.57 & 1.46 & 0.05 & $2.07^{* *}$ \\
CD $(0.05)$ & $1.16^{* *}$ & $2.93^{* *}$ & $0.11^{* *}$ & \\
\hline
\end{tabular}

$* *$ Significantly differs

dormancy and dormancy breaking treatments. The response of seeds to imposed treatments showed that the red sander pods possess combined dormancy (physical and physiological), which can be overcome or broken by leaching of pods for 72 hours in water followed by 12 hours soaking in 500 ppm $\mathrm{GA}_{3}$.

\section{REFERENCES}

BASKIn JM \& BASkIN CC. 2004. A classification system for seed dormancy. Seed Science Research 14: 1-16.

DAYANAND T \& Lohidas T. 1998. Effect of different treatments on pod germination of red sanders (Pterocarpus santalinus L.). The Indian Forester 11: 87-88.
Kalimuthu K \& Lakshmanan KK. 1995. Effect of different treatments on pod germination of Pterocarpus species. The Indian Forester 18: 104-106.

Maguire JD. 1962 Speed of germination-aid selection and evaluation for seedling emergence and vigor. Crop Science 2: 176-177.

Malick CP \& Singh MB. 1980. Estimation of polyphenols Pp 286 in Malik et al. (eds) Plant Enzymology and Histo Enzymology. Kalyani Publishers, New Delhi.

MAYNARD ML \& GATES DH. 1963. Effects of wetting and drying on germination of crested wheatgrass seeds. Journal of Range Management 16: 119-121.

Moussa H, Margolis HA, Dube P \& Odongo J. 1998. Factors affecting the germination of doum palm (Hyphaene thebaica Mart.) seeds from the semi-arid zone of Niger, West Africa. Forest Ecology and Management 104: 27-41. 
NaIdU CV \& Rajendrudu G. 2001. Influence of kinetin and nitrogenous salts on seed germination of red sanders (Pterocarpus santalinus Linn. F.). Seed Science and Technology 29: 669-672.

Omakhua GE, Aigbe HI \& Ndulue NB. 2015. Effects of pre germination treatments on the germination and early seedling growth of Tetrapleura Tetraptera. International Journal of Scientific and Technology Research 4: 160-164.

Padmalatha K \& Prasad MNV. 2007. Seed germination studies in Pterocarpus santalinus L.F. - an endangered and endemic medicinal plant, and relevance to conservation. Seed Science and Biotechnology 1: 32-34.

Rao S \& Raju AJS. 2002. Pollination ecology of the red sanders Terocarpus santalinus (Fabaceae), an endemic and endangered tree species. Current Science. 83: $9-10$.
REDDY KK \& SRIVASUKI KP. 1990. Vegetative propagation of red sanders (Pterocarpus santalinus Linn.). The Indian Forester 116: 536-540.

Shilpa B, Reddy CS, Sudha K, Sudhakar S \& Raju VS. 2012. Vegetation cover mapping and landscape level disturbance gradient analysis in Warangal district, Andhra Pradesh: India using satellite remote sensing and GIS. Advances in Space Research 1: 29-38.

Thanuja PC, Nadukeri S \& Shashikala SK. 2019. Enhancement of seed germination rate and seedling vigour index in red sanders (Pterocarpus santalinus Linn. F.): an endangered tree medicinal plant through different pre-sowing seed treatments. The Pharma Innovation Journal 8: 523-525. 